\title{
Entevista com Luis Alberto de Abreu'
}

Por Stephan Baumgärtel ${ }^{2}$

$\int$ uais são os impulsos cênicos e/ou sociais que possuem mais impacto em seu trabalho enquanto dramaturgo?

Talvez por não ser diretor, alguém que trabalhe diretamente com o ator e os equipamentos teatrais, o meu maior impulso cênico sempre foi o palco vazio. A imagem de um palco vazio sempre me pareceu estímulo cênico suficiente e me impulsionou a buscar formas de preenchê-lo, de estabelecer relações possíveis entre ele e a plateia. Até hoje um palco vazio é para mim um mistério e exerce um grande fascínio. Algo desse palco vai em direção à plateia, às pessoas. Há algo a ser revelado, alguma coisa de grande importância tem de ser partilhada, um segredo que é impossível de ser guardado, e o local é esse, o palco. Esse é, em geral, meu primeiro impulso, diria o impulso gerado pela linguagem. Os impulsos sociais são fundamentos complementares e não menos importantes. Poder, opressão, a morte e o pequeno ser humano enredado nesses mecanismos me fascinam e atraem.

Qual é a função da palavra e do texto teatral em suas montagens (ou dispositivos cênicos)?

Gosto das palavras, principalmente de sua eloquência poética, de sua capacidade de envolvimento, mas no teatro sua função é sempre complementar e acessória. Nesse sentido, interessa-me mais sua função me-

\footnotetext{
1 Luís Alberto de Abreu (São Bernardo do Campo SP 1952). Autor, roteirista de cinema e TV, professor, consultor de dramaturgia e roteiro. [...] Luís Alberto de Abreu escreve em estreita colaboração com companhias de teatro, porém sua dramaturgia alcança autonomia literária. Fonte: http://www.itaucultural.org.br/aplicexternas/enciclopedia_teatro/index.cfm?fuseaction=personalidades_biografia\&cd_verbete=254. Acesso: 30 jun 2013.
}

diadora, de transmissão e expressão dos conflitos humanos. Interessa-me principalmente a experiência humana, toda (a tola, a trágica, a filosófica), e as palavras me interessam enquanto intermediárias entre as ações da experiência humana e as pessoas.

Qual é a função e a importância da tradição dramática em seu processo dramatúrgico?

Para mim, a função e a importância da tradição dramática são muitos grandes. A tradição dramática tem sido muito questionada nos dias de hoje e é bom que assim seja. Ela é limitada, como de resto qualquer linguagem igualmente o é. Nenhuma dá conta total da complexidade do ser e da sociedade, por isso o atual momento é muito estimulante no que diz respeito à revisão da eficácia de cada uma delas e novas conformações delas nas obras. No entanto, tenho muita resistência em abandonar a tradição dramática, primeiro porque são ainda formas eficientes de organização cênica e comunicação. Segundo porque reconheço na tradição dramática elementos constitutivos da própria linguagem teatral. São esses elementos que organizam a linguagem que me interessam, não os artifícios do gênero. É nesse sentido que resisto em abandoná-los

Do seu ponto de vista, quais são as barreiras e riscos mais iminentes que a dramaturgia brasileira contemporânea precisa enfrentar?

A principal barreira, em minha opinião, é o público. E o que chamo de pú- 
blico não é o público restrito, pagador de ingressos. Público para mim são todos. Às vezes tenho a impressão que o teatro se restringe a um gueto e não gosto de guetos. O problema fundamental é como conversar com o público de um lado e, de outro, como partilhar questões fundamentais e comuns. Há toda uma pesquisa teórica e filosófica que precisa transformar-se em cena eficiente. Se de um lado há uma pesquisa contundente por outro vejo o teatro muito confortável, sem contradições humanas e sociais profundas. $\mathrm{O}$ mundo está estilhaçado em inúmeras fraturas e o teatro está bem posto e confortável. Imagino sempre que estamos perdendo contato com o público, me questiono sempre se o que mostro é importante para o público. Não gostaria de ver no teatro o mesmo destino da ópera que ainda sobrevive dos grandes autores do século XIX.

Como você vê a importância das oficinas de dramaturgia as quais você administrou e como você vê os resultados concretos delas?

É muito difícil avaliar os resultados concretos delas, isso o tempo vai apontar. O que sei é que dramaturgia era um termo praticamente desconhecido e os dramaturgos atuantes cabiam na palma de uma mão. Hoje o estudo da dramaturgia faz parte do dia a dia do teatro e praticamente não existe um grupo que não pratique a própria dramaturgia ou não interfira no processo de sua construção. Nesse sentido alguma coisa mudou no teatro e essa coisa foi importante. Creio que contribui um pouco para que isso acontecesse.

Como você vê o papel do Estado no processo de construir e consolidar uma Dramaturgia Brasileira Contemporânea?

Há que se dividir o papel que o Estado desempenha e a função dele. O Estado brasileiro continua ainda grosseiro e filistino. É desalentador ver o Estado assumir os mesmos valores da iniciativa privada: mer- cado e público pagante, arte como produto mercadológico. Essa é a mentalidade geral. Com exceção de medidas pontuais aqui e ali, nada mudou, em substância, no papel do Estado desde os séculos anteriores. O papel do Estado sempre esteve aquém do necessário e não vejo muitas possibilidades de mudança a curto e médio prazo. A exemplo de uma empresa, o Estado continua uma outra forma de fazer negócios, ponto!

Tem algo que você considera importante para complementar estas questões?

Acredito que todo ser humano tem uma função social. Reconheço que isso é uma forma de crença laica, uma forma de enfrentar a maior questão filosófica do ser humano que é "o que significa viver?" Estou sempre me perguntando qual é a função do artista porque creio que vá além do divertimento do público ou de ocupar seu lugar no mercado. Transformar o mistério do mundo em uma relação de troca monetária é amesquinhar o ser humano, o artista, o mundo. Talvez esse impulso seja busca de um éden ateu, de uma idade do ouro mítica. Mas não importam as definições, penso que somos impelidos a isso. 